\title{
Die wonder en wondervertelling gesien teen die agtergrond van mite en ontmitologisering
}

\author{
PJ van der Merwe
}

\begin{abstract}
Miracle and miracle narrative against the background of myth and demythologizing.

Religio-scientific perspectives on communication, language, reality conception, myth and the world of the sacred, as well as a different angle on demythologizing, are utilised in formulating a broad theological view of miracles, miracle experiences and miracle narratives.
\end{abstract}

Min onderwerpe is so ingewikkeld en ryk as die wonder, wonderervaring en wondervertelling. Dit is ook moeilik om te ontstrengel aan die menigte van verwante sake wat dit vergesel. Tog word dit in die teologie gewoonlik as 'n geabstraheerde saak hanteer. Dogmatiek is dalk die vak wat hom die meeste hieraan skuldig maak, want daar word die wonder meestal as 'n sistematiese beginselsaak hanteer. In die eksegetiese vakke word dit weer as 'n literêre saak hanteer, met klem op die kommunikatief-literère aspek. Telkens vind daar 'n mate van reduksie plaas, iets wat in studie natuurlik nie maklik te vermy is nie maar wat 'n verskraalde begrip tot gevolg het. Die bedoeling van hierdie artikel is nie om die verskynsel wonder en wonderervaring teoreties te verklaar nie, maar om die onderwerp godsdienswetenskaplik te belig en die waarde aan te toon van ' $n$ benadering wat meer 'makro' is as wat gewoonlik die geval is.

'n Voorbeeld van 'n abstrakte benadering is die filosofiese en logiese analise van David Hume. Hy sien die wonder as 'n gebeurtenis wat 'n natuurwet oorskry en wat die wilsgevolg is van 'n goddelike of een of ander onsigbare mag. Aangesien natuurwette nie oorskry kan word nie,

- Hierdie artikel is ' $n$ verwerking van 'n referaat wat gedurende 1986 'n seminaarreeks in die Fakulteit Teologie (Afd A), Universiteit van Pretoria, oor die wonder en wondervertelling ingelei het. 
is wonders onmoontlik. Oënskynlike wonders kan ò wetenskaplik verklaar word òf is gebeurtenisse waarvan onvoldoende gegewens beskikbaar is vir 'n wetenskaplike verklaring. 'Wonders' bestaan dus alleen vir sover naïewe gemoedere gebeurtenisse as sodanig ervaar.

Michell (1983) dui aan dat Hume 'n wonder so definieer dat dit ingevolge sy natuurwetenskapsbeskouing op 'n teenstrydigheid neerkom. Hume het naamlik die universele en absolute geldigheid van natuurwette aanvaar. Dit vorm 'n teenstelling met die moderne standpunt wat aan 'wette' as waarskynlikheidspatrone dink en wat 'n dinamiese en vloeibare opvatting van die natuur- en materiële werklikheid het.

Michell besef egter nie dat Hume in 'n metodologiese slagyster getrap het nie (waaraan hy self in 'n sekere sin ook nie ontkom nie). Hume kom tot sy slotsom omdat hy in ' $n$ 'metodekokon' (in hierdie geval van 'n logies-positiwistiese benadering) vasgevang was. Michell kom tot 'n ander slotsom, nie soseer omdat hy die voordeel het van metodologiese distansie en gevorderdheid of omdat hy oor beter fisikakennis beskik nie, maar omdat sy betoog wesenlik 'n teologiese betoog is en hy gevolglik 'n ander metodebenadering volg. Kritici sou kon sê dat sy veronderstellings en instelling eweneens 'n ander slotsom as waartoe hy gekom het, onmoontlik sou maak.

Die mees frustrerende aspek van Hume se behandeling van wonders is egter dat hy die saak in geidealiseerde vorm hanteer. Michell beweeg in sy teologiese hantering van die saak ietwat breër, maar slaag ook nie daarin om die ingewikkeldheid, polivalensie en rykdom van die verskynsel te verdiskonteer nie, omdat hy dit net as ' $n$ dogmatiese beginselsaak hanteer.

Bloot die vraag wat dit is waarna ons vra, dui die noodsaak van 'n breër benadering aan deurdat dit iets van die ingewikkeldheid van die onderwerp aan die lig bring. Michell verwys na Baker's dictionary of theology se definisie in dié verband en noem dit ' $n$ 'standard definition of miracle, representative of a biblical position' (Michell 1983: 51). Dit lui soos volg:

A miracle is an observable phenomenon effected by the direct operation of God's power, an arresting deviation from the ordinary sequences of nature, a deviation calculated to elicit faith-begetting awe, a divine inbreaking which authenticates a revelational agent.

Daar word dus gewerk met die veronderstelling dat dit moontlik is om 'n wonder essensieel los te maak van sy subjektiewe belewenis, diegene 
wat dit ervaar het, sy kommunikasie en sy kommunikator, en hierdie geabstraheerde (miskien geïdealiseerde) saak aan logiese of teologiese spekulasie te onderwerp. So iets moet noodwendig tot 'n verskraalde 'teologie van wonders' lei.

In werklikheid kan min met wonders as sodanig gedoen word, gewoon omdat daar geen praktiese manier is om dit te bestudeer sonder dat dit berig is nie (vgl ook Ward 1982: 214vv). Dit is selfs ' $n$ vraag of daar so iets soos 'n wonder as sodanig, dit wil sê sonder belewenis, kan bestaan. Wanneer 'wonders' of 'wondertekens' ter sprake is, mag die subjektiewe ervaring, interpretasie en mededeling daarvan dus nie uit die oog verloor word nie.

' $n$ Wonder of wonderervaring wat nie gedeel of meegedeel word nie, kom verder neer op 'n gebeurtenis wat individueel en geïsoleerd beleef word. Rudolf Otto het in sy monumentale werk, Das Heilige (1917), die oorsprong van godsdiens teruggevoer na die mens se ontmoeting met die heilige dimensie. Hierdie ontmoeting kan individueel sowel as in gemeenskapsverband plaasvind. In individuele verband kan dit persoonlike vroomheid stig en versterk. Dit is egter eers wanneer so 'n ervaring met ander gedeel word of aan hulle meegedeel word dat ons godsdienstige tradisie kry. Feitlik alle persoonlike godsdiens en belewenis koppel op een of ander wyse terug na die tradisionele en gemeenskaplike. Dit is in hierdie verband dat die betekenis van 'n godsdienswetenskaplike inset by die bestudering van die wonder en wonder vertelling blyk, omdat dit die groter konteks en dekor ook aan die orde stel.

Ek wil vervolgens die onderwerp teen die agtergrond van die volgende dekorstukke skilder: kommunikasie en werklikheidservaring, en mitiese en sakrale wêreldbeeld. Daarna word die vraag oor mite in die Bybel en die Christendom oorweeg en ten slotte word gevra of 'n na-kritiese verwondering nog moontlik is.

\section{KOMMUNIKASIE EN WERKLIKHEIDSERVARING}

Een van die konstitutiewe elemente van die mens se wêreld is kommunikasie. Kommunikasie is meer as die sigbare, hoorbare en leesbare verskynsel daarvan. Dit sluit taal, metafore, simbole en gedrag in. Dit reik tot in die wese van die mens se bestaan, identiteit, selfverstaan en ontwikkeling. Sonder kommunikasie is dit onmoontlik om met ander mense kontak te maak, maar meer as dit: dit is onmoontlik om met jouself kontak te maak. Deur die innerlike dialoog wat op sy beurt 
gestimuleer en gevoed word deur die sosiale kommunikasie, vind die mens homself en groei hy. Sielkundiges gaan so ver as om te sê dat die verhouding wat 'n persoon met sy medemens het, in 'n groot mate die verhouding weerspieël wat hy met homself het, en ook dat persoonlike identiteit en selfbeeld die wyse weerspieël waarop 'n persoon met sy medemens en gemeenskap omgaan. Outisme en skisofrenie word byvoorbeeld deur sekere geleerdes na 'n kommunikatiewe disfunksie teruggevoer.

Net so word die mens se verhouding met en verstaan van sy werklikheid en wêreld konstitutief bepaal deur die invloed wat sy sosiale omgewing op hom het. In die kennissosiologie word byvoorbeeld die verskynsel van ' $n$ 'sosiale en kommunikatiewe verifikasie' aanvaar. Die implikasie daarvan is dat waarheid en kennis grootliks afhanklik is van wat in die gemeenskap as waar aanvaarbaar is. In 'n gemeenskap waar wonders en wondertekens byvoorbeeld alledaagse begrippe is, is dit ondenkbaar om aansprake van wonderervarings nie ernstig op te neem nie. Aan die ander kant veroorsaak 'n kennismilieu soos die van die moderne Weste dat dergelike aansprake by voorbaat met agterdog bejeën word. Die vraag waarmee die kennisteorie dus worstel, is wanneer waarheid en kennis waar is. Dit word veral 'n probleem as dit om buitengewone sake soos wonders gaan.

Die wêreld en werklikheid waarin die mens hom bevind, word nie kamera-agtig deur die mens ervaar en verdiskonteer nie, maar interpretatief. Die mens ervaar dit deur middel van 'n teoretiese model wat hy vir homself, onder invloed van ander, daarvan konstrueer. Die boustene van so ' $n$ model is begrippe of opvattings. Elke begrip slaan op 'n aspek van die werklikheid en kan in 'n sekere sin ' $n$ mini-hipotese genoem word wat' $n$ bepaalde verstaan van die betrokke aspek verteenwoordig. Begrippe is boustene van kommunikasie en taal. Taal en kommunikasie dra egter ook by tot kennis- en begripsbou deurdat die individu so deel kry aan die gemeenskaplike kennis en voortdurende vloei van idees. 'n Mens kan dus hoogstens van 'n spiraalmatige progressie van kennis praat. Waarheid en kennis kan nooit van gangbare opvattings losgemaak word nie. Daarom is dit onregverdig om ' $n$ vorige era se opvattings en kennis (soos dat wonders moontlik is en inderdaad gebeur) sonder meer as 'naïef' of ongeldig af te maak. Sulke oordele gaan van die naïewe standpunt uit dat huidige kennis en opvattings waar is. Nie alleen is enige mensekennis, soos almal behoort te weet, voorlopig nie, maar dit is grootliks tydsgebonde en van sosiaal 
gangbare en relativeerbare opvattings afhanklik - meer as wat die meeste mense graag sou wou weet of erken.

Kommunikasie, taal en bestaande kennis is gevolglik van sleutel-, ja selfs konstitutiewe en bepalende, betekenis in die mens se kognitiewe verhouding met homself, sy medemens sy gemeenskap en sy wêreld. In die wêreld van die godsdienste lei hierdie werklikheid tot die opvatting dat taal in sekere omstandighede skeppingskragtig, heilig of magies is. Met taal kan werklikheid geskep word. Dit is wat soms gebeur in vertelling. 'n Vertelling hoef nie altyd werklikheidsgetrou te wees om waar te wees nie, want dit skep self werklikheid. Met taal kan 'n mens ook na die ewige waarheid en ewigheid self tas. Iets hiervan kom in die mite na vore.

\section{MITIESE EN SAKRALE WÊRELDBEELD}

In die wêreld van die primitiewe mens word die werklikheid nie analities, gedifferensieerd, saaklik en gedistansieerd beleef nie, maar in terme van die geheel, homolities, magies, persoonlik, partisiperend en met verwondering. Die beginsel van verwondering hang ook saam met die interessante teorie dat droommetafore en mitiese metafore nie verniet soveel ooreenkom nie. Van Baaren (1960: 170) verwys na die Australiese inboorlinge wat van die mitiese oertyd as die 'droomtyd' praat. Campbell (1959) het 'n uitgebreide Jungiaanse teorie van mite hieraan gekoppel. Die Afrikaanse skrywer, Etienne le Roux, se skryfidioom gaan ook op 'n Jungiaanse verstaan van mites terug. (Kyk ook Naudê 1986). Wat wel duidelik is, is dat die skeidslyn tussen die stoflike en onstoflike, tussen die werklike en droomagtige in die wêreld van mites nie baie skerp is nie.

Meer spesifiek word die term 'mite' gebruik vir 'n stuk gesproke of geskrewe tradisie wat bedoel om groot geheimenisse, belangrike sake, beginsels, wentelpunte en dies meer in die natuurwêreld, die mensewêreld, die geskiedenis en die gemeenskap te verklaar. 'Verklaar' moet nie rasionalisties of intellektueel opgeneem word nie. Dit geskied verhalend, sinspelend, metafories, simbolies, intuïtief en simpaties. Die mite is geleefde realiteit. Die oerwerklikheid (of tydstransenderende werklikheid) word deur die mite teenwoordig gestel. Deur die mite word aan die hede 'n dimensie verleen wat tyd transendeer. (Hier kom ons naby Noordmans uit met sy visie van die ewigheidsdimensie wat deur die evangelie aan die hede van die gelowige mens verleen word.) 
Mite loop normaalweg oor in sy komplement rite, wat kortweg gedramatiseerde mite genoem kan word. Dit beteken nie dat die mite altyd voor die rite kom nie, want daar is rites bekend wat tot mites aanleiding gegee het (Van Baaren 1960: 168). Die mite moet voortdurend vloei en verander om te bly lewe. Dit word geleef en beleef, aangevul, met nuwe aksente of in nuwe gestalte oorgedra. Op dieselfde wyse is die 'boodskap' daarvan iets plasties wat voortdurend aangepas kan word. Wanneer ' $n$ mite nie meer geleef word en die tyd van die betrokkenes op transenderende wyse aanspreek nie, is een van die eerste tekens daarvan dat dit wegval uit die rituele 'liturgie'. So 'n mite word dan 'n sage, legende of sprokie (Widengren 1969: 182).

Die mities-sakrale wêreldbeeld geld baie wyer as die streng primitiewe. Van Leeuwen (1966) maak hier van 'n verdere kategorie gebruik, naamlik 'ontokrasie'. Dit is 'n lewens- en wêreldbeskouing waarvolgens die skepping en skeppergod uit dieselfde oerstof afkomstig geag word en daar in die laaste instansie nie so ' $n$ wesenlike verskil tussen sakrale en profane bestaan as wat ons moderne Westerlinge geneig is om te glo nie. Net so min as wat die godheid stelling teenoor die skepping kan inneem, kan die mens dit teenoor sy wêreld doen.

Die 'sakrale' en bonatuurlike is allesbehalwe 'n vreemde dimensie in diê wêreld. Manifestasies van bonatuurlike mag of teenwoordigheid word as van groot betekenis geag. So iets sal byvoorbeeld gebeure wees wat as wonders of wondertekens ervaar of geïnterpreteer word.

Die ontmoeting met die sakrale dimensie word beide in terme van geluk en ongeluk, van heil en onheil, van redding en gevaar ervaar. Die skeidslyn tussen dié aspekte is minder as 'n haarbreedte. Die numineuse is iets wat beide aantrek en afskrik, wat tot ekstase èn angs kan lei. Die mitiese wêreld is een waarin verwondering en vrees hand aan hand gaan. Manifestasies van 'n bonatuurlike teenwoordigheid of mag is nie iets wat iedereen sou soek nie, omdat niemand vooraf kan weet wat die afloop daarvan sal wees nie. Soos Eliade (1959) ook aangetoon het, is daar in alle godsdienste ' $n$ bepaalde spanning tussen die sakrale en die profane.

Gelukkig is die mens wat dergelike ervarings oorleef om agterna daarvan te vertel. As hy nie voorheen aansien in die gemeenskap gehad het nie, sal hy dit hierna hê, veral as die verdere lot van sy mense of gemeenskap as gevolg van so 'n berig, mededeling of boodskap verander en die verandering voordelig is. Dan sien ons hoe die verskynsel van vertelling in werking tree. Die oorspronklike berig word aangevul, versier en gedramatiseer en verkry 'n vorm en funksie wat dit 
aanvanklik nie gehad het nie - iets soortgelyks aan die verskynsel van die vaticinia ex eventu. Dit is een van die maniere waarop mites, legendes en sages tot stand kom en uitgebou word. Dit word vermoed dat baie mites, veral die met 'n historiese pretensie, een of ander historiese kern het waaromheen die mite vorm aangeneem het, amper soos kristalle wat rondom enige kerndeeltjie, al is dit van vreemde materiaal, saampak en vorm. Wat die oorspronklike kerndeeltjie was, is meestal onmoontlik om agterna vas te stel. In aangepaste en gekwalifiseerde sin geld dit waarskynlik ook vir baie Bybelse wondervertellings.

Persone van wie die funksie in die gemeenskap verg dat hulle gereeld hierdie soort gevare as beroepsrisiko's moet trotseer, naamlik priesters, profete en regeerders (laasgenoemde in terme van hulle sakrale rol), verwerf status en gesag namate hulle suksesvol die rol van tussenganger tussen mense en bonatuurlike magte of wesens speel. Dikwels is hulle sukses toe te skryf aan goeie mensekennis en leierskap, maar dan word die sukses nogtans sakraal geïnterpreteer. Een van die mees algemene maniere waarop gesag, sy dit godsdienstig, sosiaal, polities of militêr, gelegitimeer en bestendig word, is deur sakralisering. Dit vind ons immers nie net by primitiewe volkere nie. So kan die stam-mite ontstaan waarin gewoonlik 'n held, 'n redder of 'n tradisiestigter as hoofkarakter optree.

'n Beginsel wat hier ter sprake is, is kousaliteitsverwarring. Vir ons gevoel werk hierdie soort argumentering slegs in een rigting: die ervaring van die numineuse teenwoordigheid of die goddelike ingrype lei tot kommunikasie daarvan wat op sy beurt aansien verleen aan die mededeler afhangende van die verdere verifikasie van sy aanspraak deur dit wat met hom of sy mense gebeur. Vir die mitiese denke kan dit egter net so wel andersom gebeur. 'n Suksesvolle leier word veronderstel iemand te wees wat suksesvol met die sakrale of goddelike sfeer kommunikeer of omgaan. Indien sy rol dit regverdig, kan hy selfs gedurende sy lewe gemitifiseer word, maar gewoonlik gebeur dit darem eers na sy dood. Hierna het die mite sy eie lewe. Dit kan aangevul word met verhale van bonatuurlike gebeure en wonders. Dikwels versmelt verskillende mites met mekaar of word legendes daarin opgeneem.

\section{'MITE' EN WONDER IN DIE BYBEL EN DIE CHRISTENDOM}

Waar sou ons die Bybelse godsdiens op so 'n skaal plaas? Dit word algemeen aanvaar dat die mitiese manier van denke en spreke op een of 
ander wyse in die Bybel figureer. Dit sou in elk geval die rykdom van wondervertellings kon help verklaar. Gunkel (1917: 102) stel egter dat daar in die Ou Testament geen gefassineerdheid of ydele nuuskierigheid oor die bonatuurlike of magiese as sodanig bestaan nie. Deurentyd is daar die neiging om die wondermatige met die almag en wil van God te verbind. Van Leeuwen meen ' $n$ totaal ander klank as die mitiese ingesteldheid in Ou- sowel as Nuwe Testament te verneem: die van teokrasie - van 'n Skepper en Verbondsgod wat die skepping uit niks in aanskyn roep, dit deur sy voorsienigheid alleen in stand hou en nie weifel om daarteenoor stelling in te neem nie. Hy skep die mens anders as wat Hy diere en plante skep - deur hom te vorm en sy asem in hom te blaas. So ontvang die mens ook iets van 'n vryheid teenoor die materiële en die vermoë om stelling daarteenoor in te neem. Die wêreld word 'n saak, gedesakraliseer en in beginsel, al is dit nie in praktyk nie, gedemitologiseer.

Dieselfde beginsel geld ook in die Nuwe Testament, maar nou aangevul met die evangeliese gedagte dat Jesus Christus die Oorwinnaar is aan wie alle mag in hemel en op aarde gegee is. Hy is die Groot Eksorsis wat die wêreld bevry van dominering deur magte van kwaad en sonde en aan diegene wat aan Hom behoort, die reg en vermoë verleen om die wêreld met vertroue in die gesig te kyk. Keller (1969: 119) kom tot die slotsom dat daar in die Bybel nie wesenlik' $n$ gretigheid na die wonder as sodanig gevind kan word nie. Wanneer dit wel voorkom, word die fokus uiteindelik na God herlei. Michell verwys na Lewis (1976) wat gestel het dat alle Bybelse wonders hulle teologiese sin vind in die 'Groot Wonder' van Jesus se opstanding. Wie die Bybelse wondervertellings wil wegverklaar, kom uiteindelik voor die Opstanding te staan. Dit is gewoonlik dan ook die plek waar die geeste geskei word.

In 'n verdienstelike poging om die hele tema 'mite' te deurdink en veral die godsdienwetenskaplike verstaan daarvan vir die teologie bruikbaar te maak, vra Pieter Schoeman (1981) dat 'mite' van sy primitiewe en pejoratiewe assosiasies bevry word en dat raakgesien sal word dat die beginsel daarvan ook in die moderne wêreld voorkom.

Schoeman wys op die verskillende wyses waarop mite in die eksegetiese vakke en godsdienswetenskap opgeneem word. Hy som Bultmann se verstaan van mite soos volg op:

'n Mite is 'n voorstelling waarin die nie-wêreldlike en die goddelike verskyn as wêreldlike en menselike; dit wat hoort tot die anderkant (jenseits) verskyn as iets duskant (diesseits). Die kultus 
wat iets tipies van die mite is, is die bemiddeling van bonatuurlike kragte deur middel van materiële middele (Schoeman 1981: 12).

Dit verskil van die opvattings van geleerdes soos Otto, Kerenyi en Eliade. Schoeman vind die vernaamste verskil daarin dat die Bultmannse definisie neerkom op die anderkantse bedeling wat die vorm aanneem van gestaltes duskant, terwyl die godsdienswetenskaplikes mite sien as die resultaat van die mens se poging om homself na die anderkant toe te projekteer. Verder maak die godsdienswetenskaplikes onderskeid tussen mitiese stof en mitiese instelling, wat die implikasie het dat die mens ook sonder om eksplisiet met mitiese stof besig te wees, mities ingestel en besig kan wees. Schoeman gaan dan verder en stel ter oorweging die vraag of die premisse dat die moderne mens nie meer dink in die argaïese, mitiese styl van 'n vroeëre denkwêreld nie, nie ' $n$ halwe waarheid is nie. Gevolglik is die mite en die mitiese mentaliteit 'n aktuele saak vir die hele teologie en wel op ' $n$ ander wyse as waarop die eksegetiese vakke dit tot dusver gehad het.

Schoeman haal Eliade en Jung aan as hy sê dat die mite vandag nog in die bewussyn van die mens voortleef en dat dit van die diepste emosionele behoeftes van die mens verteenwoordig, naamlik om tyd te transendeer. Die moderne mens het homself met sy gedesakraliseerde en empiristiese wêreld- en geskiedenisbenadering vasgevang in ' $n$ ingekapselde, uitsiglose tyd. Daarom kry ons 'n nuwe soort 'mite' waarmee gepoog word om dié tronkmure te ontvlug, byvoorbeeld 'n terugvlug na 'n wêreldonttrokke, fundamentalistiese godsdiens of 'n ontvlugting in kuns, sport, ontspanning en dergelike aktiwiteite wat tyd relativeer. Die duidelikste vorm is egter ideologieë waarmee gepretendeer word om die hede te verklaar aan die hand van ' $n$ redelike of wetenskaplike verstaan van en visie op die verlede en toekoms.

Hieruit vloei heelwat implikasies vir die teologie voort, waarvan Schoeman 'n paar uitspel. Vir die eksegetiese vakke beteken dit in elk geval dat ' $n$ hele nuwe lig op die mitiese elemente van die Bybel val. Die basiese boodskap van die Bybel is nie wesenlik mities nie. Tog is mites en mitiese elemente die erdekruike waarin ons die skat ontvang het en in baie gevalle steeds die enigste wyse waarop ons die skat kan dra en koester. Die Bultmanniaanse ontmitologiseringsprogram word gevolglik onder 'n vraagteken gestel. Enige ontmitologisering wat daarop ingestel is om die 'transendentale vate waarin God sy genadige openbaring gegiet het', te verbrysel en die mens en sy wêreld te 'humani- 
seer', is ongenadig en hou die gevaar in dat ons die 'hele diepte van sy wysheid', kan verloor (Schoeman 1981: 18). Dit kan daartoe lei dat die mens tot 'n uitsiglose tyd en bestaan van hier en nou verdoem word. Meer nog, dat hy van die hede vervreem raak, omdat dit hom van die ewigheid vervreem.

Aan die ander kant waarsku hy ook teen 'n godsdiens en teologie wat slegs met die ryk van ewige idees en ewige waarhede besig is, want dit is ook ontvlugting en lewer die wêreld aan die magte uit. Jesus Christus is beide ewig en histories, beide goddelik en menslik. Daarom is Hy en sy evangelie nie wesenlik mities nie, maar daar bokant verhewe. Die ware ontmitologisering is een wat ewigheidsgetrouheid nastreef, terwyl dit wêreldvreemdheid bestry, wat Christus as die vervulling van die mens se mitiese verlange laat sien.

Die vraag is voorts hoe ontmitologisering in die hedendaagse Christendom en kerk, veral met betrekking tot die voortgaande behae met mirakels en bonatuurlike belewenisse, moet verloop. Moet so' $n$ gesindheid ook as erdekruike met sagte handskoene hanteer word, of moet dit juis in die stryd teen wêreldvervreemding aktief teengestaan word? So 'n vraag bring ons egter op 'n nuwe veld te staan, waarin velerlei nuwe faktore waaronder dié van die sielkunde in aanmerking geneem moet word. Daarom kyk ons slegs nog na die Middeleeuse mirakelkultuur.

Keller (1969: 119) vra saam met Gunkel hoe dit moontlik was dat daar onder Jode en Christene gedurende die Middeleeue so 'n gretigheid na wonders en manifestasies van die bonatuurlike kon posvat. Ward (1982) sê dat 'n mens selfs van 'n mirakelkultuur sou kon praat.

Dieselfde beginsel wat ons vroeër gestel het, geld hier ook: die wonder of wonderteken word opgeneem as teken van goddelike nabyheid. In die Room-Katolisisme het daar nooit 'n noemenswaardige ontmitologisering op dreef gekom nie. 'n Verskil is wel getref tussen wonders en wondertekens aan die een kant en manifestasies van die bonatuurlike aan die ander kant. Wonders is sonder uitsondering ervaar as betoning van goddelike grasie en soms is ook openbaringsbetekenis daaraan geheg. Manifestasies van die bonatuurlike het egter iets van die ambivalensie van gevaarlik en tegelyk voordelig behou. Dink byvoorbeeld aan die Middeleeuse geloof aan heksery en magie, en die magiese praktyk wat aanvanklik met medewerking van die kerk ontwerp en toegepas is om hekse te ontmasker.

Die onderskeid wat die kerk tussen wonders en magie gemaak het, het hom gaandeweg gedwing om teen sulke praktyke stelling in te neem. Eksorsisme wat self heelwat magiese aspekte vertoon het, het 
egter voortgegaan. In beginsel is nogtans probeer om mense aan te moedig om in plaas van magie hulle hoop te vestig op wondertekens van heiliges of wondergebeure wat hulle op heilige plekke te wagte kon wees (byvoorbeeld die genesende waters van Lourdes (vgl ook Ward 1982: 10vv).

Miskien is aangevoel dat die verskil tussen magiese gebeure en kerklike wonders daarin geleë is dat eersgenoemde ' $n$ dinamistiese inslag het en laasgenoemde ' $n$ animisties-personalistiese. Wonder wat met die heiliges, sy dit voor of na hulle afsterwe, verbind kan word, dui op die vermoë en goddelike aanvaarbaarheid van die betrokkenes. Tog kan die dinamistiese, amper magiese, element nie altyd verdoesel word nie en dikwels staan dit in wonderberigte uit (vgl ook Van der Leeuw 1967: 30, 33). Verder doen wonderberigte die aansien van sulke afgestorwenes, en gevolglik die kerk, natuurlik geen skade nie.

Dit sou ' $n$ fout wees om die Middeleeuse mirakelkultuur op die verlengstuk van die Bybelse wonders en wondervertellings te plaas. Dit is essensieel anders - waarskynlik die nawerking van 'n primitiewe en mitiese mentaliteit van die soort waarvan ons vroeër gepraat het, wat hom nie maklik laat kersten het nie. Dieselfde verskynsel doen hom ook in die geledere van jong kerke, veral in die separatisme, voor.

Aan die ander kant word ' $n$ behae in bonatuurlike ervarings vandag ook aangetref onder Christene wat ' $n$ mens aan die ander kant van die spektrum sou stel. In sulke gevalle sien ons egter 'n ander faktor aan die werk: die van reaksie en ontvlugting. Dit is dus 'n soort terugvlug in ' $n$ godsdiens waarin die buitengewone gesoek word in 'n poging om die beperkinge van die hede te bowe te gaan.

\section{'N CHRISTELIKE NA-KRITIESE VERWONDERING}

Die stelling is al gemaak dat die Reformatoriese tradisie met sy beklemtoning van die nugtere woord, teenoor ' $n$ belewenis-geloof, te eensydig geword het en die poorte wyd oopgegooi het vir die rasionalisme. Otto (1917) waarsku teen die verarmende effek van rasionalisering en pleit vir 'n godsdiens- en lewenshouding waarin verwondering weer 'n regmatige plek sal inneem. Uiteindelik is die geheim van menswees en die heilswerklikheid van God-met-ons iets wat woorde, verklarings en rasionaliserende teologiserings ver te bowe gaan. Rasionalisme (en empirisme) beteken 'n een-dimensionalisering van lewe en menswees. Die mens sny hom af van die volheid van belewenis, verstaan en kommunikasie. Dit kan verstaan word as so 'n godsdiens- 
styl 'n reaksie in die teenoorgestelde rigting tot gevolg het. Dit sou ook ironies wees as 'n ontmitologiseringsprogram wat in vlak rasionalisme eindig, uiteindelik sulke vrugte dra.

'n Breër verstaan van die kennis- en kommunikasiestyl van die wêreld waarin die Bybel sy beslag gekry het, toon die armoede aan van 'n rasionalistiese en abstrakte hantering van sake soos die wonder, wonderervaring en wondervertelling. 'n Na-kritiese verstaan van kennis, nie alleen van Bybelse tye nie, maar ook van die huidige, kan nie anders as om ' $n$ mens tot nederigheid in sy waarheidsaansprake te bring nie. Begrip van die mitiese mens laat ons besef dat ons self nie in 'n posisie is om al te maklik oordele te vel nie.

Beteken dit dat die deur vir wonderaansprake nou wyd oopgegooi word? Nee, tereg sê Schoeman dat Jesus Christus ons 'n duidelike ontmitologiseringstaak oplê. Dit geld nie net ten opsigte van die Skrif nie, maar ook ten opsigte van ons eie wêreld en lewe. Die basiese dwaling van die mite is dat dit die mens nie tot die regte verstaan van en regte verhouding tot die werklikheid en die hede bring nie, alhoewel dit pretendeer om dit te doen. Slegs die ewige Christus en sy boodskap is daartoe in staat. Daarom moet alles wat aan hierdie volle Waarheid wil afbreuk doen, ons daarvan wil weglei of verlei, aan die kaak gestel word. Dit is nogtans nie 'n taak wat triomfalisties en sonder simpatie uitgevoer kan word nie.

Uiteindelik kom dit neer op 'n Christelik-kritiese ingesteldheid, maar daarmee saam ook 'n na-kritiese verwondering en naïwiteit, die kern van wat ons geloof noem.

\section{NAWOORD}

Graag wil ek hiermee waardering betuig teenoor prof $\mathrm{CH}$ Rautenbach vir jarelange vriendskap en vele hartlike en leersame gesprekke. Dat hy 'n groot geleerde is, ly geen twyfel. By meer as een geleentheid in sy lang loopbaan het hy blyke van wysheid gegee. Sy hele lewe is egter getuienis van sy geloof in en sy trou aan die Heer van die kerk. Ek ag dit' $n$ eer om hierdie artikel aan hom op te dra en hoop dat dit sy statuur waardig mag wees.

\section{Literatuurverwysings}

CAMPBELL, J 1959. Masks of God: primitive mythology. New York: Viking Press. ELIADE, M 1959. The sacred and the profane. New York: Harcourt, Brace \& World. 
GUNKEL, H [1917] 1921. Das Märchen im Alten Testament, in Religionsgeschichtliche Volksbücher für die deutsche christliche Gegenwart I, 23-26. Tübingen. (Aangehaal in Keller 1969: 116.)

KELLER, E \& M-L 1969. Miracles in dispute. Londen: SCM.

LEWIS, CS 1976. Religion and science, in Hooper, W (ed) 1976. God in the dock. Grand Rapids: Eerdmans. (Aangehaal in Michell 1983.)

MICHELL, LJ 1983. Miracles, natural laws and Christian theology. Theologia Evangelica 16, 51-58.

NAUDE, JP 1986. Die skeppingsmites as simbole van psigiese prosesse. HTS 42, 753-763. OTTO, R [1917] 1971. The idea of the Holy. Vertaal deur Harvey, JW. Hersiene uitgawe. Londen: Oxford University Press.

SCHOEMAN, P 1981. Mitologie en godsdiens. Theologia Evangelica 14, 10-22.

VAN BAAREN, TP 1960. Doolhof der goden. Amsterdam: Querido.

VAN DER LEEUW, G 1963. Religion in essence and manifestation. Vertaal en bygewerk deur Smith, P, Gloucester, Mass.

VAN LEEUWEN, AT 1966. Het Christendom in de wereldgeschiedenis. Hilversum: Paul Brand.

WARD, B 1982. Miracles and the medieval mind. London: Scholars.

WIDENGREN, G 1969. Religionsphänomenologie. Berlyn: De Gruyter. 